\title{
The Ripple Effects of Performance Management on Employees'Perceptions and Affective Commitment among Small and Medium Scale Enterprises (SMEs)
}

\author{
Anita Asamany ${ }^{1} \&$ Sun Shaorong ${ }^{1}$ \\ ${ }^{1}$ School of Business, University of Shanghai for Science and Technology, 516 Jun gong Rd, Shanghai 200093, China \\ Correspondence: Anita Asamany, School of Business, University of Shanghai for Science and Technology, 516 Jun \\ gong Rd, Shanghai 200093, China.
}

Received: November 21, 2017

Accepted: December 21, 2017 Online Published: January 3, 2018

doi:10.5430/ijba.v9n1p55

URL: https://doi.org/10.5430/ijba.v9n1p55

\begin{abstract}
Management literature acknowledges the important role played by performance management systems (PMS) in business organization, however, a little empirical studies exist in the Ghanaian context.

Using a sample data of 180 from managements and staffs of thirty-eight (38) Small and Medium Scale Enterprises (SMEs), the current study presents the effects of performance management systems on employees perception and organizational commitment (affective) among Small and Medium Scale Enterprises (SMEs) located in the Greater Accra region of Ghana.

Statistical Package for Social Sciences 20.0 version (SPSS) and Microsoft Word 2010 were employed for the data analysis. From the result, performance management had a positive significant relationship with employees' perceptions and affective organizational commitment.

The study further examined the mediating role of both employees' perceptions and affective commitment on performance management towards operational performance, it was revealed that both variables positively mediate the relationship between performance management and organizational performance of the SMEs in Ghana. This indicates that SMEs in Ghana have seen the need for implementing proper performance management systems based on their own capabilities to ensure effectiveness in meeting the organizational objectives.
\end{abstract}

Keywords: performance management, affective commitment, employees' perceptions, small and medium scale enterprises (SMEs)

\section{Introduction}

The economy of Ghana over the years has witnessed a significant growth, and this development according to Abrokwah et al. (2015) is credited to the activities of the small and medium scale enterprises (SMEs) in the country. In line with this, the government of Ghana in the first quarter of 2017 opened its arms for individual and group investors to apply directly through the Ministry of Local Industry for "one district one factory" (ghanaweb.com), a project which aims at strengthening and boosting the activities of the second sector economy, which in the past have had a dramatic impact on the economy of Ghana. However, their activities in recent years are becoming less productive and have witnessed a lower endurance and progress rate (Yang, 2015), as a result of the immense growth of competition and strategic planning among businesses today.

A current study in Ghana revealed that $60 \%$ of SMEs fail within the first five years of operation (Boachie et al, 2005; Abrokwah et al, 2015). Upon these facts, the study is designed to examine the impact of performance management systems on employees' perceptions and affective commitment among the Ghanaian SMEs in their attempt to gain a competitive advantage.

This is an indication that SMEs and their systems and processes are liable to the power of human perceptions. For the Ghanaian SMEs to survive, they have to continuously reinvent themselves in the direction to remain competitive, as recalled by Abrokwah et al, (2015).In this study it was revealed that both variables (employee's perception and affective commitment) positively mediate the relationship between performance management and organizational performance of the SMEs in Ghana. 
The effect is therefore the need for a study that do not only acknowledges the important role of Performance Management Systems as a strategic tool among businesses but also look out for the tie among Affective Commitment, Employees Perceptions and Performance Management in a developing country like Ghana, for the benefit of adequate empirical studies to policy makers, owner-managers, business consultants etc.

\section{Theoretical Background and Hypothesis}

\subsection{Theoretical Review}

This study is premised on the process control and the organizational fairness theories which both advocate for fairness in an organization. According to the process control theory, management control system will determine the perception of fairness which will lead to organizational outcome. Thus, an employee will be influence when the view of a particular control system is deemed fair. Alike, organizational fairness theory also help examine the individual behavior and effort for fairness. These theories share the same view on fairness. That is, the more control employees have of the PMS, the more they will consider the processes fair. Process control theory states that control of the process is important to people for instrumental reasons: that control of the process will result in outcomes that are more encouraging to the individual since control is entrusted in the participants (Latham, 2011). It also suggests that fairness perceptions are driven by the level of control that individuals are capable to exercise over processes that determine outcomes (Caplow \& shavell, 2000). In particular, the process control focus on interventions such as the participation of the employees in the process and their level of knowledge about the content of the actions being adopted.

Overall, fairness is a valid dimension for inclusion in economic models since fairness matters to people. (Pulakos, 2004; Gruman and Saks, 2011) noted possible outcomes of an effective PM as a) clarifying job responsibilities and expectations, b) enhancing individual and group productivities, c) emerging employees' capabilities to their completest extent through effective feedback and coaching, d) driving behavior to make even with the organizational core values, goals and strategies, e) providing a basis for making operational human capital decision (e.g. Pay) and f) improving communication amongst managers and employees. Thus, a clear system of performance management will lead to employees' behaviors as shown in figure 1 below;

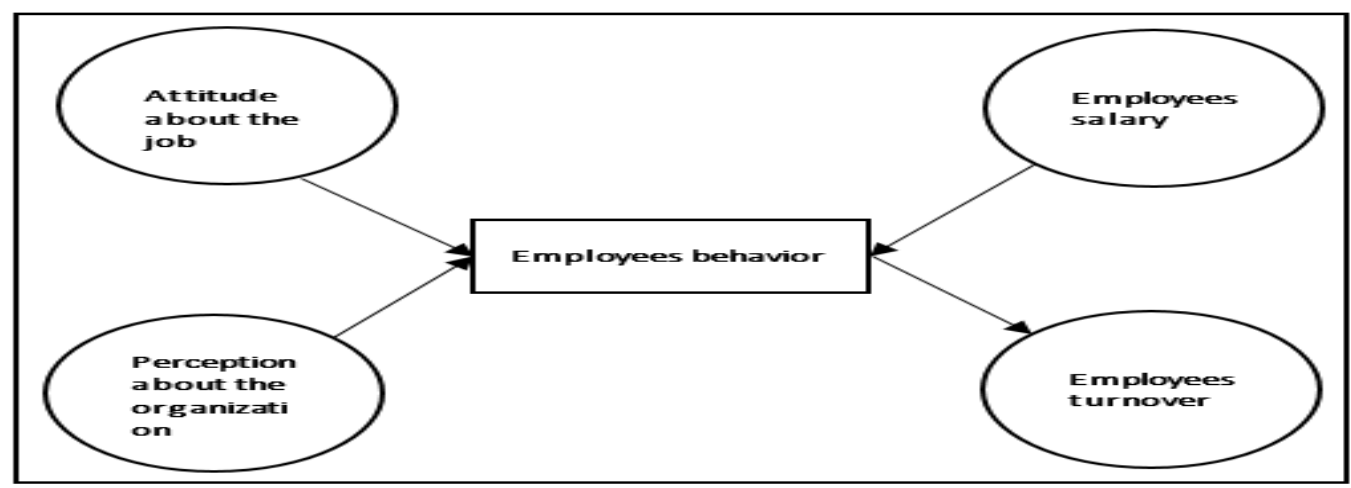

Figure 1. The influence of performance management practices on employees' behaviors

Authors' construct

\subsection{Performance Management and Affective Organizational Commitment}

Successful organization knows how to win today's competitive world, they must attract, develop and retain talented and productive employees. Organizations' get their competitive edge from the commitment (affective) its put into performance management system that helps them to hire talented people, provide continuously training and assessment for them to be the right people always (Arumugam, 2001).

The concept of performance management is grounded on the belief that organization's commitment (affective) is dependent on employee's performance management. Performance Management is a rudimentary action to regulate the activities of an organization (Pradhan and Chaudhary, 2012). Armstrong (2010) discourses that the performance management system has positive influence on organizational commitment (affective). In the sense that the 
accessibility of opportunities for development, advancement growth, and acknowledgement will greatly rise the commitment and motivational level among employees. Performance management offers data for manpower preparation. Explicitly the ability record for organizational commitment is gathered through employee's performance management system of an organization. Thus, performance management embeds strategic goals in organizational commitment (affective). Suliman and Lles (2000) explore the organizational commitment and performance management in three industrial departments. Their study disclosed that organizational commitment is a three dimensional concept and it has positive relationship with performance management.

\subsection{Employee Perception and Affective Organizational Commitment}

Samson (2010) states that the reasons for studying organizational commitment are related to"employees perceptions and performance effectiveness, attitudinal, emotional, and cognitive concepts such as job satisfaction, characteristics of the employee's job and role, such as duties and lastly personal characteristics of the employee such as age and job tenure. According to Adler and Corson (2003), employees perceptions on job satisfaction was found absolutely correlated with affective commitment. Employees are continuously re-evaluating their commitment to an organization. Why? They want and expect specific outcomes for the effort they give to the organization (Riketta, 2002).

When the outcome they get is not as what they perceived, it may reduce the willingness of the particular employee to constantly employ effort into the job given and this may then affect the commitment of employees towards the organization. Results of research on commitment examines whether the different components of commitment have certain consequences. The commitment outcomes that are broadly studied include employee retention, attendance, organizational citizenship, and job performance. However, the results of the above are all intertwined with the perception employees hold towards organization and so its affective commitment (Hartmann, 2000).

Employee's perception is therefore imperative in every organization, thus how people feel may affect the decision they make or their behavior towards work which may affect the commitment of an organization as a whole. When employees perceived the organization is not committed to them, they may be inserting not as much of effort in doing their daily work. Employees who have this kind of perception may not be necessarily based on the reality but it is merely a view of them in a situation (Samson, 2010). Consequently, there should be at least a balance in employees'perceptions and the commitment (affective) of an organization.

\subsection{Performance Management, AOC and Employee's Perception}

A performance management is a planned and cohesive approach to deliver continuous success to organizations by improving the performance of the people who work in organizations. This can be done by developing a keen organizational commitment that considers the capabilities of teams and individual contributions. A good PMS enables the organization to understand how its employees are currently performing. It allows organizations to know their commitment level in terms of thorough assessment of the training needs of its employees, set progress plans and gives them the possibility of using the result of the performance management process to influence an individual remuneration (Adams, 2007).

Organizations can achieve their goals and objectives only through the combined efforts of their employees' performance and their commitment task of managing their performance to get work done. Performance management is ultimate to the effective commitment of organizations.

That is linking of employees' activities to organizational strategy, communicating organizational expectations, evaluating employee's progress, making employment decisions, rewarding performers and developing non-performers as well as keeping a record of human resource decisions. Varma et al., (2008) sum up the purpose of performance management as "the system through which organizations agreed work goals, determine performance principles, dispense and appraise work, provide performance response, determine training and development needs and allot rewards. Therefore, managing employee performance enables the effective delivery of strategic and operational goals. There is a strong and direct correlation between using performance management programmers to enrich business and organizational results since the perception of fairness impact the way people think and feel (Shrivastava and Purang, 2011).

PMS incorporates all those features of human resources management (for example boosting employees' organizational commitment and perception) that are intended to improve the efficiency and effectiveness of both the individual employee and the organization. Meyer et al. 1990; Vallejo 2009: Boichuk and Menguc (2013) suggest that employees with strong affective commitment remain because they want to (perception), those with resilient continuance commitment because they need to (perception) and those with strong normative commitment because 
they feel they have to do so (perception). It is now broadly known fact that perception of fairness, impact the way people think, feel (Shrivastava and Purang, 2011), and act to achieve results. Therefore, we suggest;

Hypothesis of the study

H1. Performance management systems are positively related to organizational performance

H2. Performance management systems are positively related to employee's perception within the organization.

H3. Performance management systems are positively related to Affective commitment within the organization.

H4. There is a positive relationship between employee's perception and affective organizational commitment.

H5. Employee's perception positively mediate the relationship between PMS and OP

H6. Affective commitment positively mediate the relationship between PMS and OP

Conceptual framework

Figure two (2) below presents the research framework in this paper, according to Korir (2014), all workers expect to be rewarded and recognized for their efforts, as such, performance management being the independent variable will be the inevitable tool in ensuring fairness in these processes of rewarding to attain affective commitment, employees perceptions and organizational performance. In this study, Affective Commitment, Organizational Performance and Employees' Perceptions were viewed to be the mediating variables of human resource management policy for an effective performance in an organization. The framework below depicts that Performance Management has a positive influence on employees' perceptions, affective organizational commitment and organizational performance taking into consideration basic controlling factors like firm age and firm size.

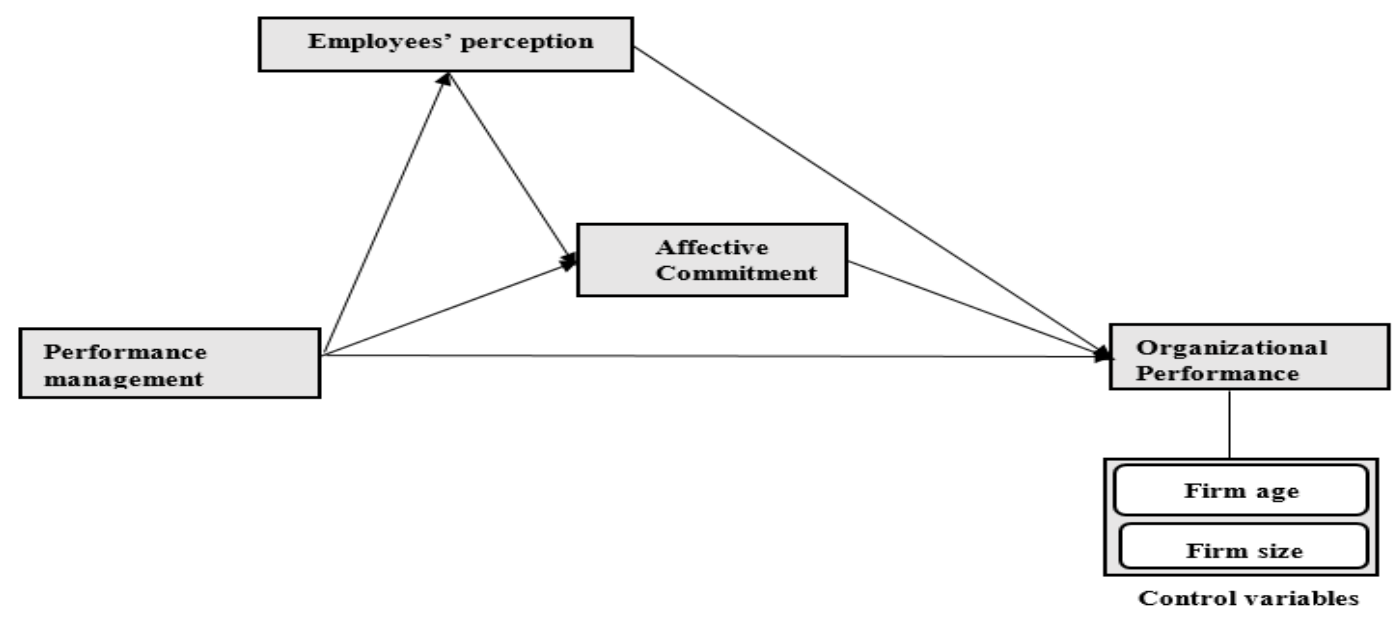

Figure 2. Conceptual framework

\section{Authors' construct}

\section{Research Methodology}

In meeting the objective of the study, descriptive research design was adopted for the study alongside the cross-sectional survey, to collect data at one point in time (Creswell, 2013). The survey approach uses structured questionnaires within a cross-sectional design for exploring the tie performance management, employees' perceptions and affective commitment. The study comprises a population of thirty-eight (38) SMEs from the National Board for Small Scale Industries (NBSSI) in the Greater Accra region of Ghana. A descriptive sample was drawn and the researchers divided the questionnaires equally among the SMEs for the purpose of generalization. These included management and employees from the selected SMEs. There were 180 participants in the sample with 
63.33\% (114) questionnaires returned which was used for the final analysis.

Opinions regarding the performance management that exist was employed from (Gruman and Saks, 2011) and measured using 8 Likert scale items with a 5-point Likert scale responses. The responses comprise 1 for strongly disagree to 5 for strongly agree as proposed by Ntiamoah et al. (2014).

Also, the study adapted the measures of firm affective commitment designed by Allen and Meyer, 1990; Abrokwah and Ge, 2017, using 8 Likert scale items with a 5-point Likert scale responses. The responses comprise 1 for strongly disagree to 5 for strongly agree. Employees' perceptions was employed from (Delbridge and Whitfield, 2001) and measured on four indicators. The questions were placed on a 5-point Likert scale comprise of 1 for strongly disagree to 5 for strongly agree.

The questions on organizational performance was adopted from (Huo, 2012), these measures comprised 10 items. The managers and employees were required to specify their level of achievement in relative to the ten measures in their companies.

In meeting the research objectives, Firm size (FS) and firm age (FA) were considered for control purposes. Firm size was measured based on the number of employees, and as companies may possess its structure and deploy numerous resources according to their size (Gilman and Raby, 2013). Firm age measures was adopted from (Liang, 2008).

Finally, data were organized and analyzed using the SPSS version 22. Cronbach alpha analysis was used to test for the validity and reliability.

Figures, tables and descriptive statistics including mean and standard deviation were generated from the SPSS. The Likert scale responses were measured by computing the mean scores from the variables and comparing with the theoretical mean scores developed by Underwood (2004). Furthermore, the study followed Baron and Kenny's (1986) approach to testing mediation.

\section{Results}

Examines the relationships between performance management (PMS) and organizational performance (OP) alongside the mediating role of employees' perceptions (EP) and affective commitment (AOC), Table 1 explores the mean, standard deviation and the correlations statistics among the variables under study. It can be observed that PMS relate significantly to OP.

Table 1. Descriptive Statistics and Correlational Results

\begin{tabular}{lllllll}
\hline Variables & M & SD & PMS & EP & AOC & OP \\
\hline PMS & 3.3579 & 0.73426 & $(0.879)$ & & & \\
EP & 3.4530 & 0.52596 & $0.573^{* *}$ & $(0.701)$ & & \\
AOC & 3.6238 & 0.50979 & $0.489^{* *}$ & $0.466^{* *}$ & $(0.692)$ & \\
OP & 3.4538 & 0.67459 & $0.322^{* *}$ & $0.179^{*}$ & $0.242^{*}$ & $(0.774)$ \\
\hline
\end{tabular}

$\mathrm{N}=114, * \mathrm{p}<0.05, * \mathrm{p}<0.01$

Table 2 presents the regression analysis of the outcomes. Results shows significant association of PMS with EP, AOC and OP so we accept the hypotheses $\mathrm{H} 1, \mathrm{H} 2$ and $\mathrm{H} 3$. Also the result shows EP was positively significant with AOC therefore we accept $\mathrm{H} 4$.

Table 2. Regression analysis

\begin{tabular}{|c|c|c|c|c|c|c|c|c|c|}
\hline \multirow[b]{2}{*}{ Variables } & \multicolumn{3}{|c|}{ EP } & \multicolumn{3}{|c|}{$\mathrm{AOC}$} & \multicolumn{3}{|c|}{ OP } \\
\hline & $\Delta \mathrm{R}^{2^{\beta}}$ & & $\mathrm{R}^{2}$ & $\Delta \mathrm{R}^{2}{ }^{\beta}$ & & $\mathrm{R}^{2}$ & $\Delta \mathrm{R}^{2}{ }^{\beta}$ & & $\mathrm{R}^{2}$ \\
\hline Control & & 0.117 & & & 0.056 & & & 0.041 & \\
\hline PSM & $0.232 * * *$ & 0.349 & $0.363 * * *$ & $0.302 * * *$ & 0.233 & $0.177 * * *$ & $0.264 * * *$ & 0.117 & $0.076 * * *$ \\
\hline
\end{tabular}


Also in Table 3 , we conducted the mediation analysis. It was found that when mediation for $\operatorname{EP}\left(\beta=0.216, \Delta \mathrm{R}^{2}\right.$ $=0.037, \mathrm{p}<0.05$, significant $)$ and AOC $\left(\beta=0.229, \Delta \mathrm{R}^{2}=0.045, \mathrm{p}<0.05\right.$, significant $)$ were tested, the impact of PMS on organizational performance became insignificant. So the mediation hypotheses H5 and H6 are accepted.

Table 3. Mediation Analysis

\begin{tabular}{lccc}
\hline Variables & \multicolumn{3}{c}{ Organizational Performance } \\
\cline { 2 - 4 } Control & $\beta$ & $\beta \mathrm{R}^{2}$ & $\Delta \mathrm{R}^{2}$ \\
EP & $0.216^{*}$ & 0.042 & $0.037^{*}$ \\
AOC & $0.229^{*}$ & 0.123 & $0.045^{*}$ \\
PSM $\rightarrow$ EP & 0.128 & 0.122 & $0.045^{*}$ \\
PSM $\rightarrow$ AOC & 0.115 & 0.085 & $0.035^{*}$ \\
$* \mathrm{p}<0.05, * \mathrm{p}<0.01, \mathrm{~N}=114$ & & 0.076 &
\end{tabular}

\section{Discussion and Managerial Implications}

Supporting results in strategic human resource management (Wang et al. 2015) existing literature, the findings in the current study shows that performance management relates positively with employees' perceptions and affective commitment alongside organizational performance (Abrokwah and Ge , 20017). This is a general confirmation (Pfeffer and Veiga, 1999) that performance management practices enable organizational performance by focusing on employees' attitudes. By narrowing the gap in this documented literature, the current study probe into the impact of performance management on employees' perceptions, affective commitment and organizational performance, and also advanced the study by looking at the mediating role, played by both employees' perceptions and affective commitment among Ghanaian SMEs. The study revealed that both employees' perceptions and affective commitment mediate the relationship between performance management and organizational performance, therefore all the hypothesis were accepted.

The authors argued that the Ghanaian SMEs are at the uppermost of their games in building rear and imitable workforce towards competitive advantage (Zailani, 2014) by implementing proper performance management systems for managing the employees' organizational relationships. Gruman \& Saks (2011) concur with Mone and london (2010) that designing the performance management process to foster employee engagement will lead to higher levels of performance, thus, it will help avoid failure as noted by Boachie et al. (2005) in the study of Entrepreneurship and Small Business Management, which shows 60\% of the SMEs fail within the first five years of operation.

Contemporary economic challenges have led organizations to advance results by increasing their consideration on performance management (Gruman \& Saks, 2011). In flipping the coin, it is thus, well noted from the analysis, performance management can be comprehended as an ongoing activity which is geared at minimalizing organizational failure through employees' perceptions and organizational commitment, as such, theories such as the resource base theory, firm's views among others should be well embraced by management in ensuring strong and fair measures towards performance management in meeting organizational stated objectives. Alike, it is well acknowledged from this study that managers and decision makers of Ghanaian SMEs have seen the necessity to strengthen business operation in a viable competitive environment. It is evident that, performance management within an organization will ensure growth, stability and market performance (Yongyi et al., 2013).

Practitioners of performance management have learnt that, achieving better results through the principal practice of performance management requires a sound technical approach, strong leadership, ever-improving experts, and a culture than constantly reinforces focus on results. Thus, an effective PMS will go a long way in guaranteeing organizational improved performance, employee's loyalty and retention.

\section{Conclusion and Future Research}

Brewster et. al., 2007; McMahon (2013), pointed out that 90 percent of U.K organizations formally assess managers via a PMS, compared with 88 percent in Greece and Sweden, 84 percent in Ireland and 81 percent in Germany. It is obvious from the study that, performance management is a strategic tool which revamp, and boost employee welfare and organizational performance (De cuyper, Van Der Heiden, 2011: Van Der Vaart et al., 2015). 
Empowering performance management systems (PMS) through fairness in its process is exceptionally worthwhile as PMS is a strategic investment in human resource with high economic returns and acts as a facilitator in almost all aspect for high organizational performance (Skaggs \&Youndt, 2004).

As noted from the analysis, Management decision leading to performance management systems (PMS) cannot be undermined since it has a great effect in ensuring standardization and sustainability in achieving competitive advantage. However, the management idea and management level of enterprise managers is still open for further improvement (Chris et. al. 2003).

Lastly, the study has proven to be effective among the Ghanaian SMEs, however, further empirical studies on the subject matter can expand our understanding by exploring the other nine (9) regions in Ghana for generalization purposes.

\section{References}

Abrokwah, E, \& Ge, Y. (2017). Mediating Role of Work Motivation: Does Organizational Commitment impact on Non-Governmental Organizations (NGOs) Performances?. Transylvanian Review Journal, XXV(17).

Abrokwah, E., Quaye, I., Omondi, C., Yaw, O., \& Sarbah, A. (2015). The Use of Information Technology (IT) among Small and Medium Enterprises (SMEs) In Financial Reporting: Evidence from Ghana. British Journal of Economics, Management \& Trade, 8(4), 258-269.

Adams, J. (2007). Managing People in Organization, Contemporary theory and practice. Cultural Human Resources Council 2012. Managing employee performance. (Last Access, 12.8.2012).

Adler, R., \& Corson, D., (2003). Organizational Commitment, Employees and Performance. Chartered Accountants Journal of New Zealand, 82(3), 31-33.

Allen, N., \& Meyer, J. (1990). The Measurement and Antecedent of effective, continuance and normative commitment to the organization. Journal of Occupational Psychology, 63, 1-18. https://doi.org/10.1111/j.2044-8325.1990.tb00506.x

Allen, N., \& Meyer, J. (1996). Affective, continuance and normative commitment to the organization: an examination of construct validity. Journal of vocational behavior, 49(3), 252-276. https://doi.org/10.1006/jvbe.1996.0043

Armstrong, J. (2010). The People Make the Process: Commitment to Employees, Decision-Making and Performance. Journal of Management, 27, 163-189.

Arumugam, G.M. (2001). Why performance management doesn’t work. People Dynamics, 18(7), 24-25.

Baron, RM., \& Kenny, D.A. (1986). The moderator-mediator variable distinction in social psychological research: Conceptual, strategic, and statistical considerations. Journal of personality and social Psychology, 51(6), 1173-1182. https://doi.org/10.1037/0022-3514.51.6.1173

Boachie-Mensah, F.O., \& Marfo-Yiadom, E. (2005). Entrepreneurship and Small Business Management. Accra: Ghana Universities Press.

Brewster, C., Sparrow, P., \& Vernon, G. (2007). International Human Resource Management (2nd Ed.). Wimbledon, Chartered Institute of Personnel and Development. C.I.P.D. Publishing.

Cardy, R. L. (2004). Performance management: Concepts, skills, and exercises. Armonk, NY: M. E. Sharpe.

Chris, W., David, H., \& JULIE, G. (2003). Results using the balanced scorecard in the public sector. Journal of Corporate Real Estate. (11) (Doctoral dissertation, University of Nairobi).

Christian, B. (2015). Advances in Production Technology, Lecture Notes on production Engineering. https://doi.org/10.1007/978-3-319-12304-2_3

Clay-W, J., HEGVEDT, K.A., \& Roman, P. (2005). Procedural justice, distributive justice: How experiences with downsizing condition their impact on organizational commitment. Social Psychology Quarterly, 68(1), 80-102.

Creswell, JW. (2013). Qualitative inquiry and research design: Choosing among five approaches. Sage.

De Cuyper, Nele Van der Heijden, Beatrice I.J.M.De, \& Witte, Hans. (2011). Associations between perceived employability, employee well-being, and its contribution to organizational success: a matter of psychological contracts?. The International Journal of Human Resource Management, 1486-1503. https://doi.org/10.1080/09585192.2011.561962 
Delbridge, Richard I., Whitfield, \& Keith, L. (2001). Employee Perceptions of Job Influence and Organizational Participation Employee Perceptions. Industrial Relations, 40(3), 472-489. https://doi.org/10.1111/0019-8676.00220

Gilman, M., \& Raby, S. (2013). National context as a predictor of high-performance work system effectiveness in small-to-medium-sized enterprises (SMEs): AUK-French comparative analysis. International Journal of Human Resource Management, 24, 372-390. https://doi.org/10.1080/09585192.2012.672447

Gruman, Jamie A., \& Saks, Alan M. (2011). Performance management and employee engagement. Human Resource Management Review, 21(2), 123-136. https://doi.org/10.1016/j.hrmr.2010.09.004

Hartmann, L.C. (2000). Organizational commitment: A Multi method scale analysis and test of effects. International Journal of Organization Analysis, 8(1), 89-108. Retrieved December 22, 2005, from https://doi.org/10.1108/eb028912

Huo, Q. (2012). Gold nanoparticle-enabled biological and chemical detection and analysis. Chemical Society Reviews, 41(7), 2849-2866. https://doi.org/10.1039/C1CS15280G

Jeffery, P. Boichuk, \& Bulent Menguc. (2013). Engaging dissatisfied retail employees to voice promotive ideals: the role on continuance commitment. Journal of retailing, 207-218. https://doi.org/10.1016/j.jretai.2013.01.001

Kaplow, L., \& Shavell, S. (2001). Fairness versus welfare. Harvard Law Review, 114, 961. https://doi.org/10.2307/1342642

Korir, F. K. (2014). Employee's perception on performance appraisal process in G4S Kenya limited (Doctoral dissertation, University of Nairobi).

Latham, G. P. (2011). Work motivation: History, theory, research, and practice. Sage.

Liang, H.S. (2008). Study on the mechanism of organizational innovation factor based on enterprise's lifecycle stage. Unpublished PhD dissertation, Harbin Institute of Technology, 2, 49-56.

Mainoo, O. G. (2011). Theory \& Practice in Counseling II. Kumasi Ghana: Erinor Ventures.

Maria, B., \& Soren, K. (2014). Coopetition- Quo Vadis? Past accomplishments and future challenges. Industrial Marketing Management, 180-188. http://dx.doi.org/10.1016/j.indmarman.2014.02.015

McMahon, G. (2013). Performance Management: Chapter 7 in Human Resource Management. Dubling Institute of Technology. Retrieved from http://arrow.dit.ie/buschmanbk

Mone, E. M., \& London, M. (2010). Employee engagement through effective performance management: A practical guide for managers. New York: Routledge.

Ntiamoah, E.B, Abrokwah E, Agyei-Sakyi, M., Siaw A., \& Opoku, B. (2014). An Empirical Analysis of Recruitment and Selection Practices in the Public Sector. International Journal of Management Sciences and Business Research, 3, 48.

Pfeffer, J., \& Veiga, J.F. (1999). Putting people first for organizational success. Academy of Management Executive, 13(2), 37-38. https://doi.org/10.5465/AME.1999.1899547

Pradhanan, J.F., \& Chaudhary, J.W. (2012). Economic Dependency on Work: a Moderator of the Relationship between Organizational Commitment and Performance. Acad Manage J, 38, 261-271.

Pulakos, E. D. (2009). Performance Management: A new approach for driving business results. Malden, MA: Wiley-Blackwell. https://doi.org/10.1002/9781444308747

Riketta, M. (2002). Attitudinal Organizational Commitment and Job Performance: A Metaanalysis. Journal of Organizational Behaviour, 23(3), 257-266. https://doi.org/10.1002/job.141

Roodt, G. (2004). Concept redundancy and contamination in employee commitment research: current problem and future directions. SA Journal of Industry Psychology, 30(1), 82-90.

Samson. (2010). Mediating Role of Organizational Commitment on HR Practices and Turnover Intention among ICT Professionals. Journal of Management Research, 10(1), 39-61.

Shrivastava, A., \& Purang, P. (2011). Employee perceptions of performance appraisals: a comparative study on Indian banks. The International Journal of Human Resource Management, 632-647. https://doi.org/10.1080/09585192.2011.543639

Skaggs, B.C., \& Youndt, M. (2004). Strategic positioning, human capital, and performance in service organizations: 
A customer interaction approach. Strategic Management Journal, 25, 85-99. https://doi.org/10.1002/smj.365

Suliman, A, \& Iles, P. (2000). Is Continuance Commitment Beneficial to Organizations? Commitment- Performance Relationship: A New Look. Journal of Managerial Psychology, 15, 407-426. https://doi.org/10.1108/02683940010337158

Tseng, C. C., \& McLean, G. N. (2008). Strategic HRD practices as key factors in organizational learning. Journal of European Industrial Training, 32(6), 418-432. https://doi.org/10.1108/03090590810886544

Van, D., Vaart, Leoni L., Bennie D. Beer, Leon C., \& Marike. (2015). Employee well-being, intention to leave and perceived employability: A psychological contract approach. South African Journal of Economic and Management Sciences. DOI: http://dx.doi.org/10.17159/2222-3436/2015/v18n1a3.

Varma, A, Budhwar, P.S., \& DeNisi, A. (2008). 'Performance Management Systems a Global Perspective' Routledge, Abingdon.

Wang, X., Hou, Y., \& Cullinane, N. (2015). How does the human resource department's client relationship management impact on organizational performance in China?. Mediate effect of human capital. South African Journal of Economic and Management Sciences, 18(3), 291-307. https://doi.org/10.4102/sajems.v18i3.686

Yang, L. (2015). Empirical study on the relationship between entrepreneurial cognitions and strategic change momentum: the moderating effect of organizational knowledge structures. Management Decision, 53(5). https://doi.org/10.1108/MD-10-2014-0602

Yongyi, S., Yi, F., Jingjing, Z, Goufeng, W., \& Nyamah, E.Y. (2013). Power Source and its Effect in Customer-Supplier Relationships: Empirical Study in Yangtze Delta. International Journal of Production Economics, 146(1), 118-128. https://doi.org/10.1016/j.ijpe.2013.03.003

Zailani, S, Iranmanesh, M, Nimbi, D., \& Jumadi, H.B. (2014). Determinants and environmental outcome of green technology innovation adoption in the transportation industry in Malaysia. Asian Journal of Technology Innovation, 22(2), 286-301. https://doi.org/10.1080/19761597.2014.973167

Retrieved

from https://www.ghanaweb.com//GhanaHomePage/business/173-factories-set-for-1-district-1-factory-roll-out-Ahom ka-Lindsay-588046 